\title{
Seismic potential around the 2018 Hokkaido Eastern Iburi earthquake assessed considering the viscoelastic relaxation
}

\author{
Makiko Ohtani*i[ and Kazutoshi Imanishi
}

\begin{abstract}
The 2018 M 6.7 Hokkaido Eastern Iburi earthquake (Iburi earthquake) occurred near the eastern boundary fault zone of the Ishikari lowlands, which is composed of a northern and southern fault. Aftershock distribution suggests the existence of a previously unknown fault (the Shallow Iburi (SI) fault) at a shallower extension of the Iburi earthquake fault. In the present study, we examined the seismic potential of the northern, southern, and SI faults based on seismological analysis and numerical simulations. The aftershock focal mechanisms infer the present-day stress field that is characterized by an ENE-SWS compression around the target faults. Slip tendency analysis shows that all target faults originally have high slip potential under the estimated stress field. We, therefore, evaluated earthquake occurrence potential on the target faults influenced by the Iburi earthquake based on the Coulomb stress ( $\triangle C F F$ ). We consider postseismic viscoelastic deformation in the viscoelastic medium with a three-dimensional structure. The present paper shows one possible scenario based on a model incorporating information currently available. The most of the entire SI fault was brought closer to rupture just after the earthquake, indicated by the positive $\triangle C F F$, which is consistent with the activation of seismicity in this region. The $\triangle C F F$ continues to increase over many years after the earthquake, which may imply a growing risk of seismic hazards along the SI fault. The distribution of the $\triangle C F F$ along the southern fault and the southern half of the northern fault is characterized by a similar depth-dependent pattern. The faults were brought closer to rupture just after the earthquake, indicated by the positive $\triangle C F F$, except for middepths along the faults. Then, the $\triangle C F F$ increases at shallow depths for a few decades after the earthquake, which suggests a continuous build-up of stress. Although the $\triangle$ CFF decreases at the deep depths for a few decades after the earthquake, it is insufficient to return the stress level to that before the earthquake. These results suggest that all target faults are in the state of increasing seismic risk after the lburi earthquake.
\end{abstract}

Keywords: 2018 Hokkaido Eastern Iburi earthquake, Seismic potential, Stress field estimation, Slip tendency analysis, Time-dependent Coulomb stress, Viscoelastic relaxation

\section{Introduction}

On September 6, 2018, the $M_{\mathrm{j}} 6.7$ Hokkaido Eastern Iburi earthquake (hereafter referred to as the Iburi earthquake or mainshock) occurred in Hokkaido, northern Japan (Fig. 1). The earthquake triggered large landslides and caused severe damage to the surrounding area. According to Japan Meteorological Agency (JMA), the Iburi earthquake occurred at a depth of $37 \mathrm{~km}$, which is deep

\footnotetext{
*Correspondence: ohtani.m@aist.go.jp

Geological Survey of Japan, AIST, Central 7, 1-1-1 Higashi, Tsukuba, Ibaraki, Japan
}

compared with usual activity of inland earthquakes in Japan. This area, including beneath the Hidaka Mountains (Fig. 1), is a region where deep inland earthquakes commonly occur (e.g., Kita et al. 2012). The centroid moment tensor (CMT) solution and aftershock distribution indicate that the mainshock occurred as a reverse faulting along a steeply eastward-dipping plane. On February 21, 2019, there was an $M_{\mathrm{j}} 5.8$ aftershock that occurred at the northern part of the aftershock area (Japan Meteorological Agency 2019), which was the largest aftershock as of April 2019. Although coseismic slip mainly occurred at depths greater than $16 \mathrm{~km}$ 


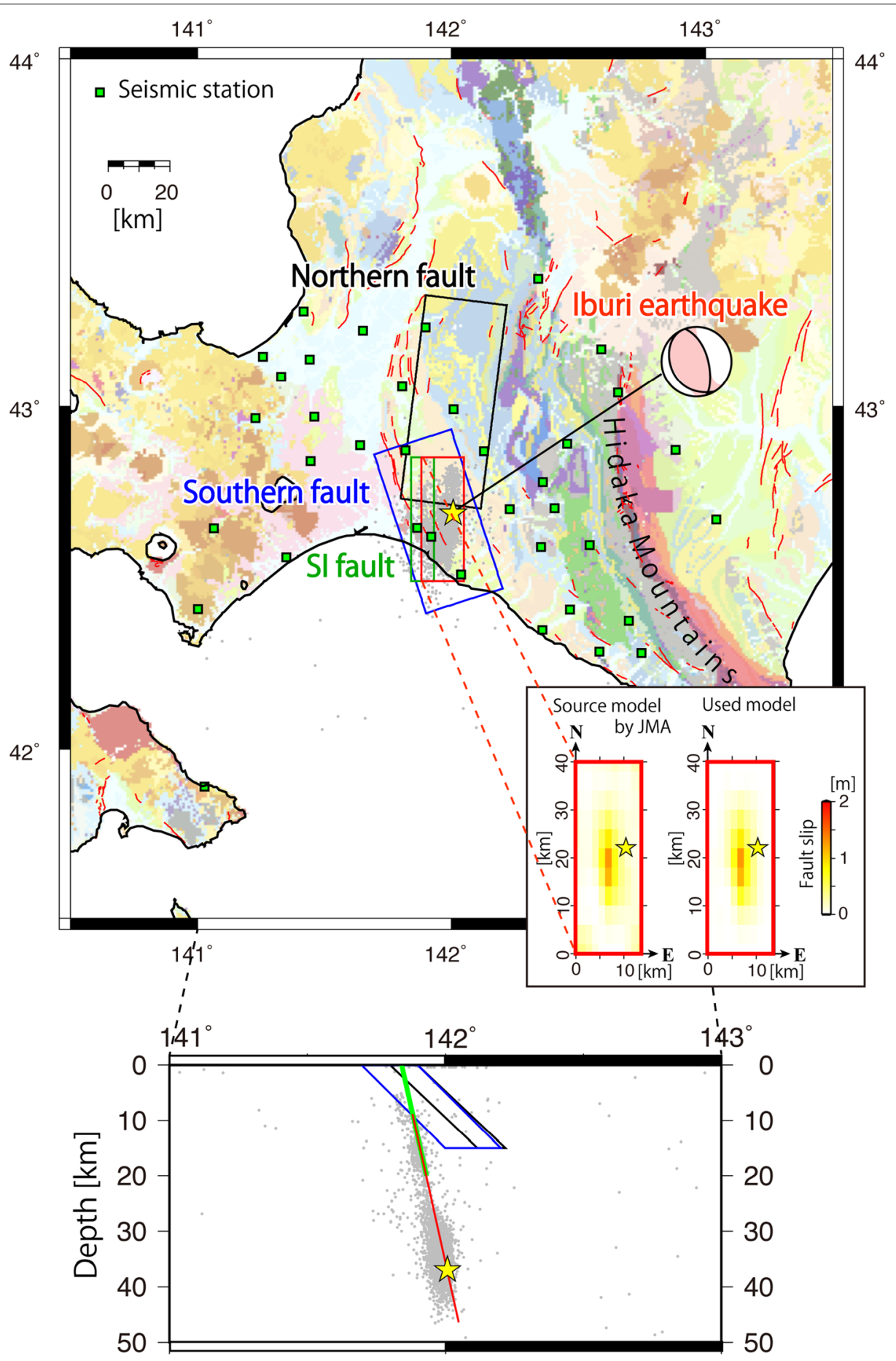

Fig. 1 Map of the lburi earthquake and the three target faults in the present study, shown with the geological map (see details in GeomapNavi; https://gbank.gsj.jp/geonavi/geonavi.php). The black, blue, and green rectangles indicate the surface projection for the geometry of the three target faults: the northern fault, the southern fault in the Ishikari fault zone, and the SI fault, respectively. The star and gray circles indicate the hypocenter of the mainshock and the 40-day aftershocks based on the earthquake catalog of Japan Meteorological Agency. The "beach ball" represents the centroid moment tensor solution for the mainshock by Japan Meteorological Agency (https://www.data.jma.go.jp/svd/egev/data/ $\mathrm{mech} / \mathrm{cmt} / \mathrm{fig} / \mathrm{cmt} 20180906030759$.html. Accessed: January 29, 2019). The red rectangle shows the surface projection of the Iburi earthquake fault estimated by Japan Meteorological Agency (2018). The original fault slip distribution and the modified distribution used in the present study are shown on the left and right of the right lower panel. Red lines indicate active faults after Research Group for Active Faults of Japan (1991). The small green squares represent seismic stations used for analysis. The location of Hidaka Mountains is also indicated. The bottom panel shows the target faults, the mainshock, and the aftershocks projected onto the E-W vertical section 
(Geospatial Information Authority of Japan 2018; Japan Meteorological Agency 2018), shallower aftershocks were also active. The tectonic structure in the Hokkaido region is characterized by thrust faults and geological units that are almost parallel to $\mathrm{N}-\mathrm{S}$ direction (Fig. 1). This $\mathrm{N}-\mathrm{S}$ trending feature indicates the long-term existence of $\mathrm{E}-\mathrm{W}$ compression, which is a consequence of westward migration of the Kuril Arc sliver and its collision with northeastern Japan due to the oblique subduction of the Pacific plate since the late Miocene (e.g., Kimura 1986). The Iburi earthquake likely occurred under a stress field caused by ongoing arc-arc collisional processes.

An active fault zone near the source region of the Iburi earthquake is known as the eastern boundary fault zone of the Ishikari lowlands (Headquarters for Earthquake Research Promotion 2010) (hereafter referred to as the Ishikari fault zone). On the basis of geological structure distribution patterns, the Ishikari fault zone is divided into northern and southern faults, where eastward-dipping thrust faultings are expected. The average vertical slip rate along the northern fault is estimated to be $0.4 \mathrm{~m} / 1000$ years or more. Along this fault, earthquakes with a vertical slip of $>2$ m repeatedly occur at an interval of 1000-2000 years with the most recent occurrence between AD 1739 and 1885. On the basis of fault length, the northern fault could potentially produce an earthquake around M7.9. The average vertical slip rate along the southern fault is estimated to be $0.2 \mathrm{~m} / 1000$ years or more. Although the history of seismic ruptures along this fault is not well constrained, this fault appears to have the potential to generate an M7.7 earthquake or larger. If an earthquake of this magnitude occurs, it will produce more destructive damage than the Iburi earthquake. Evaluating earthquake potential in the Ishikari fault zone is therefore important.

In the present study, we discuss the potential for future ruptures along the northern and southern faults in the Ishikari fault zone. In addition, we also focus on a fault inferred from aftershock distributions of the Iburi earthquake. The fault is a shallower extension of the Iburi earthquake fault as estimated by Japan Meteorological Agency (2018) (Fig. 1); hereafter, we call it as the Shallow Iburi (SI) fault. Details for the three target faults are listed in Table 1. The target faults are located at depths shallower than the mainshock fault, i.e., at depths from 0 to $15 \mathrm{~km}$ for the northern and southern faults and from 0 to $20 \mathrm{~km}$ for the SI fault.

First, we infer the present-day stress field around the target faults based on aftershock focal mechanism solutions ("Slip tendency of the target faults under the present-day stress field" section). On the basis of the estimated stress field, we evaluate the slip potential for the target faults using a slip tendency analysis. Next, in
Table 1 Source parameters for the three target faults: the northern, southern, and SI faults (Fig. 1 black, blue, and green rectangles)

\begin{tabular}{llllll}
\hline & Strike $\left(^{\circ}\right)$ & $\operatorname{Dip}\left({ }^{\circ}\right)$ & Rake $\left(^{\circ}\right)$ & Length $(\mathbf{k m})$ & $\begin{array}{l}\text { Depth } \\
\text { range } \\
\mathbf{( k m )}\end{array}$ \\
\hline Northern fault & 7 & 30 & 90 & 66 & $0-15$ \\
Southern fault & 342 & 30 & 90 & 54 & $0-15$ \\
SI fault & 0 & 70 & 106 & 40 & $0-20$ \\
\hline
\end{tabular}

"Stress change due to the Iburi earthquake in an elasticviscoelastic medium" section, we calculate the stress change along the target faults due to the Iburi earthquake and derive the Coulomb stress, which is modified by an inelastic strain evolution in a viscoelastic medium with a three-dimensional (3-D) structure. Then, we discuss the long-term effects that the Iburi earthquake has on the target faults. We should note that, at present, no observation data (seismicity or ground surface deformation) exist that are comparable with time-dependent results because only 7 months have passed since the Iburi earthquake as of April 2019. However, a rapid evaluation of the stress change allows a discussion on the potential for a future earthquake.

\section{Slip tendency of the target faults under the present-day stress field}

Prior to evaluating the stress change caused by the Iburi earthquake, we investigate the slip tendency of the target faults based on the present-day stress field. Since shallow seismicity in the area was low before the Iburi earthquake, the stress field there has not been quantitatively estimated (e.g., Yukutake et al. 2015). Shallow aftershocks of the Iburi earthquake provide an opportunity to infer the stress field by a suite of focal mechanism solutions.

\section{Data}

We focused on 45 shallow aftershocks that occurred between September 6 and November 18, 2018, which had JMA magnitude $\left(M_{\mathrm{j}}\right)$ larger than 1.8 and focal depths at less than $22 \mathrm{~km}$. The largest event was $M_{\mathrm{j}} 4.3$, which occurred at 12:54 (JST) on September 11. Only this event's focal mechanism (reverse faulting type) was routinely determined by JMA and National Research Institute for Earth Science and Disaster Resilience. Data for these analyses derive from regional high-sensitivity seismic stations (Fig. 1). We determined hypocenters of the earthquakes by applying a maximum-likelihood estimation algorithm (Hirata and Matsu'ura 1987) to manually picked arrival times. The velocity model used in the present study (lower right panel in Fig. 2a) is a 

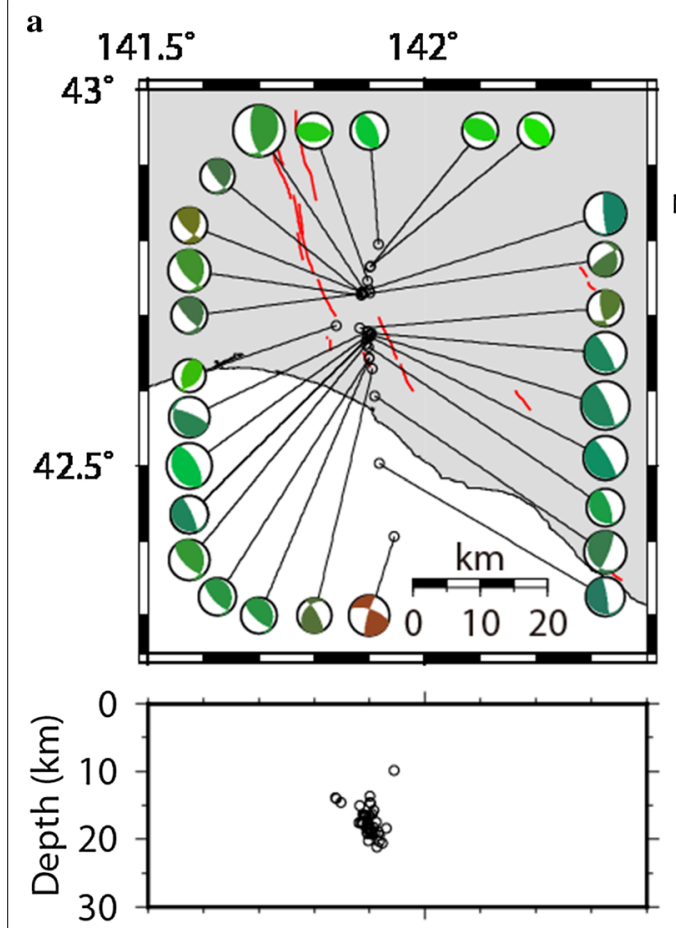
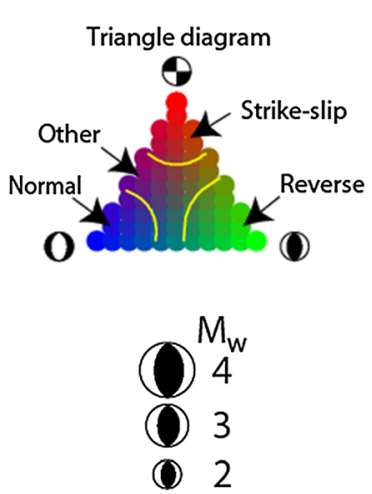

$\mathrm{V}_{\mathrm{p}}(\mathrm{km} / \mathrm{s})$

0246810



b
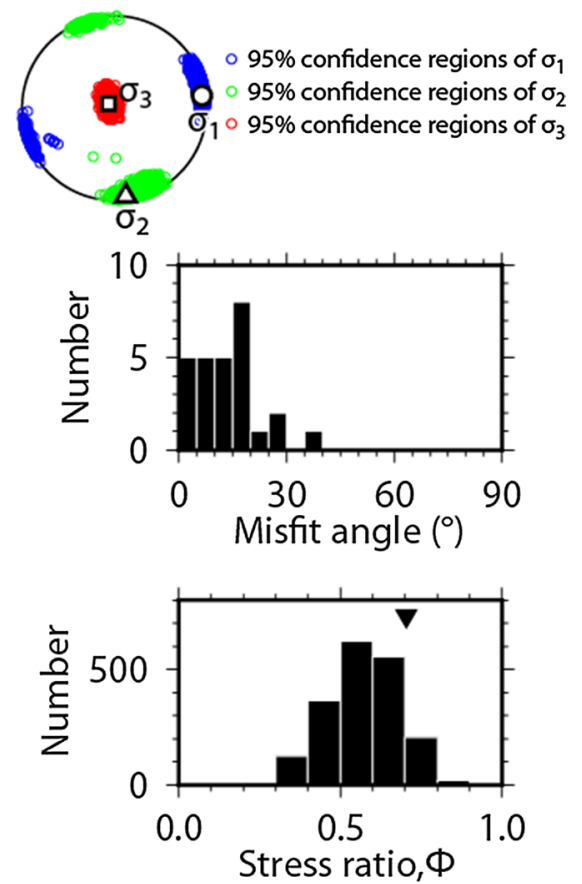

Fig. 2 a Focal mechanism solutions for the 27 aftershocks determined in this study (lower hemisphere of the equal-area projection) with colors used to differentiate between the reverse (green), strike slip (red), and normal faulting (blue) mechanisms. A triangle diagram (Flohlich 1992) with a color scale is presented at the top right. Open circles indicate relocated hypocenters derived using the velocity model shown in the bottom right. The S-wave velocity is assumed by scaling the P-wave velocity by a factor of $1 / \sqrt{3}$. $\mathbf{b}$ Results of the stress tensor inversion. The top panels show the principal stress axes with their $95 \%$ confidence regions plotted on the lower hemisphere stereonets. The middle panel shows the misfit angle for the data with respect to the best stress tensor determined by the stress tensor inversion. Here, the misfit angle represents the angular difference between the tangential traction predicted by the best solution and the observed slip direction on each focal mechanism. The bottom panel shows the frequency of the stress ratio $\varphi$, which belongs to the $95 \%$ confidence region. Inverted triangle represents the stress ratio of the best stress tensor

one-dimensional (1-D) velocity structure that contains low-velocity layer beneath the source region (Iwasaki et al. 2004). We first located the hypocenters for all events without station corrections. We then relocated the hypocenters by introducing station corrections, which were computed by averaging the differences between the observed and theoretical travel times at each station. We repeated the procedure until the reduction in the root mean square (RMS) for the arrival time residuals had converged. After three iterations, the RMS decreased from 0.437 to $0.135 \mathrm{~s}$ for the P-wave and from 0.907 to $0.280 \mathrm{~s}$ for the $\mathrm{S}$-wave. The average spatial errors calculated using the maximum-likelihood estimation algorithm were $205 \mathrm{~m}$ horizontally and $253 \mathrm{~m}$ vertically, which are sufficient for the objectives of the present study. The circles in Fig. 2a show the relocated aftershocks, which suggest that they align along the $\mathrm{N}-\mathrm{S}$ direction and dip eastward at a high angle of about $70^{\circ}$. Compared with the distribution of
JMA catalog, the relocated aftershocks clustered, but overall features did not change.

\section{Determination of focal mechanism solutions and stress field}

We then determined focal mechanism solutions for the aftershocks using absolute $\mathrm{P}$ - and $\mathrm{SH}$-wave amplitudes, as well as P-wave polarity (see detail procedures in Imanishi et al. 2011). The 27 focal mechanisms, with at least 10 P-wave polarities and a variance reduction of $>50 \%$, are plotted on the map shown in Fig. 2a. On the basis of definitions by Flohlich (1992), most events are categorized as reverse faulting. Interestingly, the strikes for each of these events slightly deviate from $\mathrm{N}-\mathrm{S}$ aftershock alignment but are more similar to the strike of the southern fault in the Ishikari fault zone.

Using the 27 focal mechanism solutions, we estimated the stress field by applying the inversion method of Michael (1984, 1987). The estimated stress parameters are as follows: the maximum $\left(\sigma_{1}\right)$, intermediate $\left(\sigma_{2}\right)$, and minimum $\left(\sigma_{3}\right)$ compressive principal stresses, as well as 
the stress ratio $\left(\phi=\left(\sigma_{2}-\sigma_{3}\right) /\left(\sigma_{1}-\sigma_{3}\right)\right)$. The result of the stress tensor inversion indicates that this area is characterized by a reverse faulting stress regime with $\sigma_{1}$ oriented to a subhorizontal ENE-SWS direction (Fig. 2b). The stress ratio is greater than 0.5 , which suggests that the magnitude of $\sigma_{2}$ is closer to $\sigma_{1}$ than $\sigma_{3}$. The ENE-SWS compressional stress is considered to be a consequence of westward migration of the Kuril Arc sliver and its collision with northeastern Japan.

\section{Slip tendency analysis}

On the basis of fault geometry (Table 1) and the estimated stress field, we can evaluate the slip potential along target faults using a slip tendency analysis. Morris et al. (1996) defined slip tendency $\left(T_{\mathrm{s}}\right)$ as the ratio of shear stress $(\tau)$ to effective normal stress $\left(\sigma_{\mathrm{n}}\right)$ that act on the plane of weakness. Following Lisle and Srivastava (2004), we used the normalized slip tendency defined as $T_{\mathrm{s}}{ }^{\prime}=T_{\mathrm{s}}$ ' $\max \left(T_{\mathrm{s}}\right)=T_{\mathrm{s}} / \mu$, where $\mu$ is the static frictional coefficient. The value of $T_{\mathrm{s}}{ }^{\prime}$ is between 0 and 1 , where larger values correspond to greater slip potential. We supposed that the frictional sliding envelope is tangential to the $\sigma_{1}-\sigma_{3}$ Mohr circle, which allows us to calculate $T_{\mathrm{s}}{ }^{\prime}$ without knowledge of the absolute stress value (Lisle and Srivastava 2004). Collettini and Trippetta (2007) defined favorably oriented planes of slip by $0.5<T_{\mathrm{s}}{ }^{\prime} \leq 1$ and unfavorably oriented planes by $0 \leq T_{\mathrm{s}}^{\prime} \leq 0.5$.

Figure 3 shows a histogram of $T_{\mathrm{s}}^{\prime}$ values computed from $95 \%$ confidence regions of the assumed stress tensor (bars), together with the best stress tensor (inverted triangle). Here, we set the static friction coefficient to 0.6. The results indicate that the present-day stress field is favorably oriented to the faults in the Ishikari fault zone
(Fig. 3a, b). Even for the SI fault, which is a high-angle fault, the $T_{\mathrm{s}}{ }^{\prime}$ value for the best stress tensor exceeds 0.5 . Furthermore, more than half of the $T_{\mathrm{s}}{ }^{\prime}$ values computed from the $95 \%$ confidence regions also exceed 0.5 (Fig. 3c). Thus, all target faults originally have high slip potential with respect to the present-day stress field, which suggests that we need to evaluate the stress change along the faults caused by the Iburi earthquake.

\section{Stress change due to the Iburi earthquake in an elastic-viscoelastic medium}

Here, we calculate the Coulomb stress change along the target faults caused by the Iburi earthquake. The Coulomb stress estimation has been employed in a number of regions and proved to be an effective method to evaluate earthquake triggering (Stein 1999; King and Cocco 2001). In the present study, we take into account the viscoelastic relaxation in the lower crust to calculate the timedependent Coulomb stress. Viscoelastic relaxation plays an important role in producing delayed earthquake triggering, such as in the 1992 Landers-1999 Hector Mine earthquakes (Freed 2005).

\section{Methods}

We employ an equivalent body force method to evaluate the stress field produced by an inelastic strain (Barbot and Fialko 2010; Lambert and Barbot 2016). Here we summarize the method. The strain field, $\boldsymbol{\varepsilon}^{t}$, is composed of the elastic and inelastic strains, $\boldsymbol{\varepsilon}^{e}$ and $\boldsymbol{\varepsilon}^{i}$. The elastic stress, $\boldsymbol{\sigma}$, is noted as $\boldsymbol{\sigma}=\mathbf{C}: \boldsymbol{\varepsilon}^{e}=\mathbf{C}:\left(\boldsymbol{\varepsilon}^{t}-\boldsymbol{\varepsilon}^{i}\right)$, where $\mathbf{C}$ is the elastic constant and (:) denotes the inner product. We can rewrite the continuum equation, i.e., $\nabla \sigma=0$, using

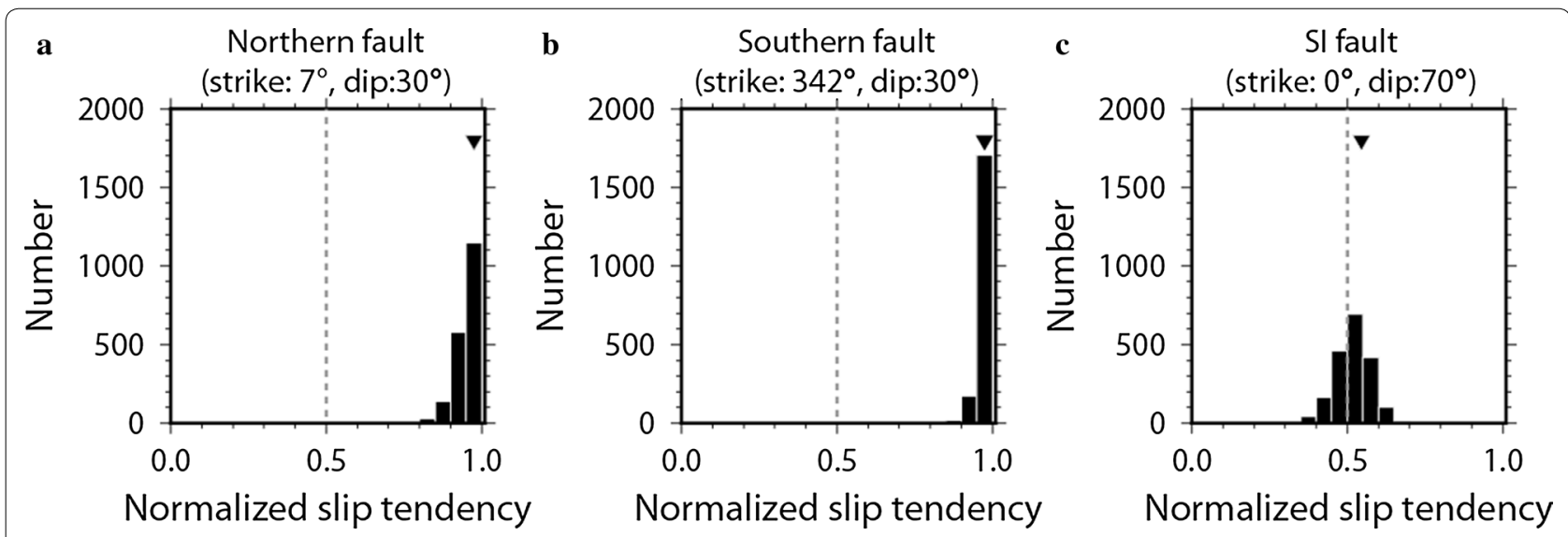

Fig. 3 Frequency of the normalized slip tendency computed from the $95 \%$ confidence region of the stress tensor in Fig. 2b. The inverted triangles show the normalized slip tendency of the best stress tensor. The gray dotted line indicates the boundary as to whether or not the fault is easy to move under the assumed stress tensor (Collettini and Trippetta 2007). For the case of a northern, b southern, and $\mathbf{c}$ SI faults 
the equivalent body force, $\mathbf{f}=-\nabla \mathbf{m}=-\nabla\left(\mathbf{C}: \boldsymbol{\varepsilon}^{i}\right)$, as follows:

$$
\nabla\left(\mathbf{C}: \boldsymbol{\varepsilon}^{t}\right)-\nabla \mathbf{m}=\nabla\left(\mathbf{C}: \boldsymbol{\varepsilon}^{t}\right)+\mathbf{f}=0 .
$$

The displacement field, $\mathbf{u}(\mathbf{x})$, is derived by solving Eq. 1, the inhomogeneous Navier's equation, and we get

$$
\mathbf{u}(\mathbf{x})=\int_{\Omega} \mathbf{G}(\mathbf{x}, \mathbf{y}) \mathbf{f}(\mathbf{y}) \mathrm{d} \mathbf{y},
$$

where $\mathbf{G}(\mathbf{x}, \mathbf{y})$ is the elastic Green's function to a point force at $\mathbf{y}$. When the inelastic strain field is discretized into volumetric cuboid cells with uniform strain and stress, $\Omega_{k}\left(k=1, \ldots, N_{v}\right)$, the displacement field is the sum of displacement produced by inelastic strain in each volumetric cell:

$$
\mathbf{u}(\mathbf{x}) \sim \sum_{k=1}^{N_{v}} \mathbf{u}_{k}(\mathbf{x})=\sum_{k=1}^{N_{v}} \int_{\Omega_{k}} \mathbf{G}(\mathbf{x}, \mathbf{y}) \mathbf{f}_{k}(\mathbf{y}) \mathrm{d} \mathbf{y} .
$$

G $(\mathbf{x}, \mathbf{y})$ is analytically derived by Barbot et al. (2017). For an inelastic strain field, $\boldsymbol{\varepsilon}^{i}(t)$, at time $t$, elastic stress field, $\boldsymbol{\sigma}(\mathbf{x}, t)$, is calculated using only the information at the time;

$$
\boldsymbol{\sigma}(\mathbf{x}, t)=\sum_{k=1}^{N_{v}} \mathbf{K}_{k}^{v}(\mathbf{x}) \boldsymbol{\varepsilon}_{k}^{i}(t),
$$

written in the form of Green's function $\mathbf{K}_{k}^{v}(\mathbf{x})$ multiplied by inelastic strain $\boldsymbol{\varepsilon}_{k}^{i}(t)$. $\mathbf{K}_{k}^{v}(\mathbf{x})$ is the $\mathbf{u}_{k}(\mathbf{x})$ for a unit of strain in $\Omega_{k}$. When no external forces is applied, the time derivatives for the stress and inelastic strain in each volumetric cell are

$$
\left\{\begin{array}{l}
\dot{\boldsymbol{\sigma}}_{k}(t)=\sum_{k=1}^{N_{v}} \mathbf{K}_{k j}^{v} \dot{\varepsilon}_{j}^{i}(t) \\
\dot{\boldsymbol{\varepsilon}}_{k}^{i}(t)=g\left(\boldsymbol{\sigma}_{k}(t)\right)
\end{array}\right.
$$

where $g$ varies depending on the deformation mechanism. In the present study, we assume Maxwell viscoelasticity, and therefore, we denote $g(\boldsymbol{\sigma})$ as $g(\boldsymbol{\sigma})=\boldsymbol{\sigma}^{\prime} / \eta$, where $\boldsymbol{\sigma}^{\prime}$ is the deviatoric stress and $\eta$ is the viscosity. We solve Eq. (5) using a time step adaptive Runge-Kutta method (Hairer et al. 1993).

In the present paper, we assume the Iburi earthquake occurs at $t=0$. For simplicity, we assume that there is no strain and deviatoric stress before the earthquake. The initial conditions at $t=0$ just after the earthquake are as follows:

$$
\left\{\begin{array}{l}
\boldsymbol{\sigma}_{k}(0)=\sum_{j=1}^{N_{f}} \mathbf{K}_{k j}^{f} \mathbf{s}_{j} \\
\boldsymbol{\varepsilon}_{k}^{i}(0)=0
\end{array}\right.
$$

where $\mathbf{s}_{j}$ is the slip on the fault cell $j\left(j=1, \ldots, N_{f}\right)$, and $\mathbf{K}_{k j}^{f}$ is the elastic stress response observed at the volumetric cell $k$ due to a unit slip in the slip direction on the fault cell $j$, which is calculated by the method of Okada (1992).

The change in stress $\Delta \boldsymbol{\sigma}(\mathbf{x}, t)$ from a reference value of just before the earthquake is calculated as the summation of the stress change due to the fault slip (coseismic stress change) and the time-dependent inelastic strain (postseismic stress change):

$$
\Delta \boldsymbol{\sigma}(\mathbf{x}, t)=\sum_{j=1}^{N_{f}} \mathbf{K}_{j}^{f}(\mathbf{x}) \mathbf{s}_{j}+\sum_{j=1}^{N_{v}} \mathbf{K}_{j}^{v}(\mathbf{x}) \varepsilon_{j}^{i}(t) .
$$

Following Reasenberg and Simpson (1992), we calculate the Coulomb stress $(\triangle \mathrm{CFF})$ along each target fault as

$$
\Delta \operatorname{CFF}(t)=\Delta \tau(t)-\mu^{\prime} \Delta \sigma_{n}(t),
$$

where $\Delta \tau(t)$ is the shear stress change and $\Delta \sigma_{n}(t)$ is the change in the stress that is normal to the fault (negative if the fault is unclamped), which is calculated from $\Delta \boldsymbol{\sigma}(\mathbf{x}, t)$. The coefficient $\mu^{\prime}$ is the effective friction, which ranges from 0 to 1 . An increase in the shear stress and a decrease in normal stress increase the Coulomb stress. Faults with a positive $\triangle \mathrm{CFF}$ value are brought closer to rupture, whereas faults with a negative $\triangle \mathrm{CFF}$ value are brought farther away.

\section{Source model for the Iburi earthquake}

For the fault slip, $\mathbf{s}$ in Eq. (6), we use a finite fault source model for the Iburi earthquake derived from an inversion of near-source strong motion data (Fig. 1; Japan Meteorological Agency 2018). The fault with a strike of $0^{\circ}$ and a dip of $70^{\circ}$ was divided into $N_{f}=100$ subfaults, where $\boldsymbol{s}_{j}\left(j=1, \ldots, N_{f}\right)$ was estimated. The fault is characterized by reverse faulting and a maximum slip of $1.65 \mathrm{~m}$. The majority of the coseismic slip occurred at depths between 15 and $40 \mathrm{~km}$, and a seismic moment of $1.5 \times 10^{19} \mathrm{Nm}$ $\left(M_{\mathrm{w}}=6.7\right)$ is released. Although the majority of the slip concentrates along the mid-depths of the assumed fault, there are also minor peaks in the slip at the rims of the fault (left in the lower right panel in Fig. 1), which are possibly less reliable than the middle main slip. Therefore, we set the slip at the rims as $0 \mathrm{~m}$. The slip distribution used in the present study for the fault model is shown at the right of the lower right panel in Fig. 1. The modified model generally explains the displacement from GNSS observation (Geospatial Information Authority of Japan 2018), other than the station closest to the mainshock, whose displacement is in the opposite direction to the observation. For simplicity, we assume that the Iburi earthquake occurs at $t=0$ and that the fault produces no slip at $t>0$, i.e., $\mathbf{s}_{j}(t)=0$ at $t>0$. 
There is another available source model, derived from an inversion of geodetic data (Geospatial Information Authority of Japan 2018). The estimated fault plane is slightly offset from the aftershock distribution and a little shallower than that used in the present paper. In spite of this difference, the calculated $\triangle \mathrm{CFF}$ for the source model by Geospatial Information Authority of Japan (2018) showed similar postseismic change to that by Japan Meteorological Agency (2018), suggesting that the present result is robust with regard to the choice of source model.

\section{Crustal model}

Cho and Kuwahara (2013b) derived the viscoelastic structure beneath the Japanese islands based on a 3-D thermal structure (Cho and Kuwahara 2013a) and flow law of rocks. The model consists of two layers: a shallower elastic layer and a deeper viscoelastic layer. The thickness of the derived elastic layer, defined as $\operatorname{depth}_{e}(\mathbf{x})$ in Fig. 4a, varies widely from $10 \mathrm{~km}$ to $45 \mathrm{~km}$ in the Hokkaido region, and the Iburi earthquake fault is located where the elastic layer is thick, i.e., $\operatorname{depth}_{e}(\mathbf{x})>40 \mathrm{~km}$. In the present study, we assume the viscoelastic medium with the 3-D structure and investigate the effects of the structure. For the objectives of the present study, however, the model of Cho and Kuwahara (2013b) has a problem that there are no data for the $\operatorname{depth}_{e}(\mathbf{x})$ beneath the Hidaka Mountains (Fig. 1) and oceanic areas. On the basis of the Moho map (Matsubara et al. 2017) and the thickness of the seismogenic layer (Omuralieva et al. 2012), we set the depth $_{e}(\mathbf{x})$ to $45 \mathrm{~km}$ under the Hidaka Mountains. For the oceanic area, we determined the $\operatorname{depth}_{e}(\mathbf{x})$ by extrapolating the existing data using the "surface" command in the Generic Mapping Tools (Wessel and Smith 1998). We further incorporated the subducting Pacific plate into the model to limit the viscoelastic layer to shallower depths than the subducting plate interface. For the plate interface depth, defined as $\operatorname{depth}_{p}(\mathbf{x})$ in Fig. 4a, we used the model estimated in Kita et al. (2010) and Nakajima and Hasegawa (2006). The colored circles in Fig. 4b show the

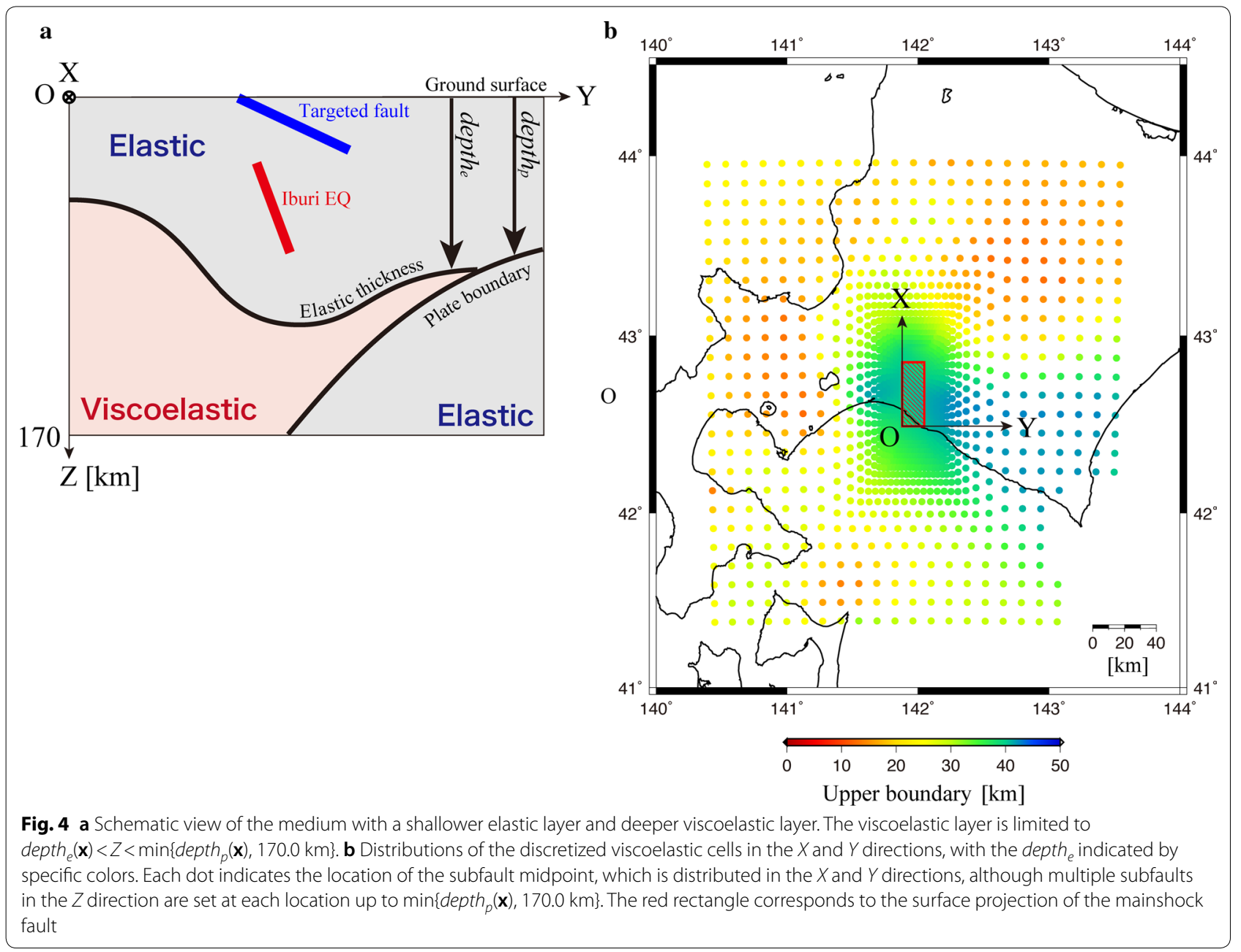


spatial distribution of $\operatorname{depth}_{e}(\mathbf{x})$, i.e., the uppermost depth of the viscoelastic layer. For both layers, we assume that the rigidity is $50 \mathrm{GPa}$ and the Poisson's ratio is 0.25 . For the viscoelastic layer, we assume that $\eta$ is $1 \times 10^{19} \mathrm{~Pa} \mathrm{~s}$, with reference to previous studies in the Hokkaido (Ueda et al. 2003; Itoh and Nishimura 2016) and Tohoku regions (Suito and Hirahara 1999; Ohzono et al. 2012).

We embed the Iburi earthquake source model ("Source model for the Iburi earthquake" section) into the crustal model (Fig. 4). Here, we set the $X$ - and $Y$-axes in the north and east directions and the $Z$-axis is depth, downward positive. We set the ground surface at $Z=0$. We discretize the viscoelastic layer into $N_{v}=45,700$ unequal-sized cuboid cells, in which the horizontal size has a minimum value of $2 \mathrm{~km} \times 1.3 \mathrm{~km}$ in the $X$ and $Y$ directions and increases as it goes away from the Iburi earthquake (Fig. 4b). We set the cell size in the $\mathrm{Z}$ direction to increase with increasing $Z$. We set the bottom limit for the viscoelastic layer to be $170.0 \mathrm{~km}$. The viscoelastic region is thus limited to $322 \mathrm{~km} \times 333 \mathrm{~km}$ in the $X$ and $Y$ directions and $\operatorname{depth}_{e}(\mathbf{x})<\mathrm{Z}<\min \left\{\operatorname{depth}_{p}(\mathbf{x}), 170.0 \mathrm{~km}\right\}$.

\section{Time-dependent $\Delta$ CFF}

We evaluated the time-dependent $\Delta \operatorname{CFF}(t)$ along the target faults (Table 1) using Eq. (8) and $\mu^{\prime}=0.4$, which value is commonly used in the calculation of $\triangle \mathrm{CFF}$ to minimize the uncertainty in $\mu^{\prime}$ (King et al. 1994). First, we

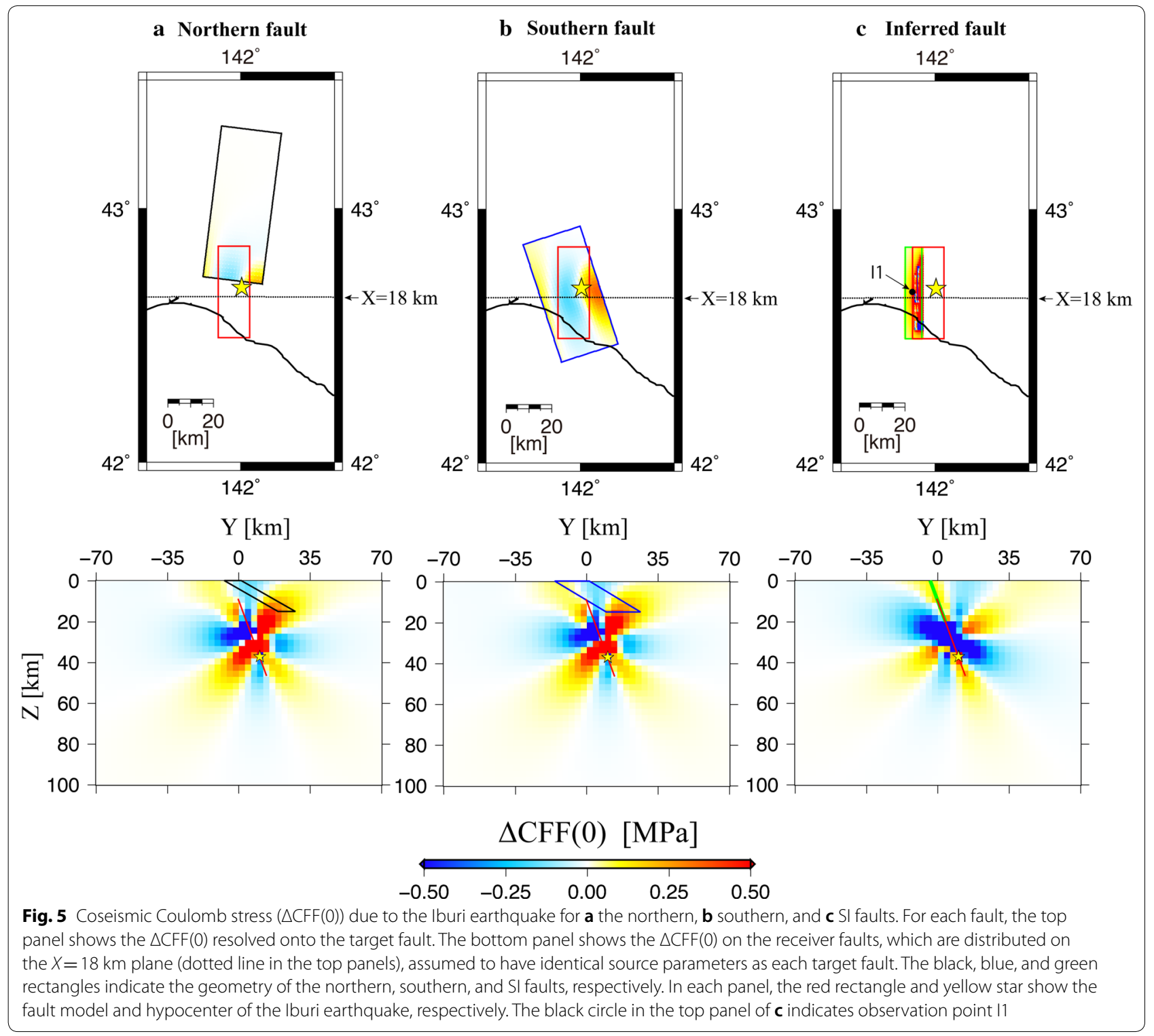


show the elastic response in Fig. 5. The top panels show the coseismic Coulomb stress $\triangle \mathrm{CFF}(0)$ or coseismic $\triangle C F F$ with the same meaning, resolved onto each target fault. The bottom panels show cross-sectional views of $\triangle \operatorname{CFF}(0)$ at $X=18 \mathrm{~km}$ for the receiver faults, which have identical fault parameters as each target fault. The SI fault has identical strike and dip as the Iburi earthquake fault, and the $\triangle \operatorname{CFF}(0)$ distribution is characterized by typical pattern for blind reverse faulting (Fig. 5c bottom; Lin and Stein 2004). The mainshock relieves stress along the slipped fault and generates stress shadows with a negative $\triangle \operatorname{CFF}(0)$ value. On the other hand, stress concentrated along both ends of the slipped fault and positive $\triangle \mathrm{CFF}(0)$ values are calculated there, which indicates that the receiver faults there are brought closer to rupture. The SI fault is located at the shallower end of the Iburi earthquake fault, so that the $\triangle \mathrm{CFF}(0)$ value is mainly positive along the fault plane. The $\triangle \mathrm{CFF}(0)$ has the value up to $6.14 \mathrm{MPa}$ (Fig. $5 \mathrm{c}$ top), which is high because the SI fault partially overlaps with the Iburi earthquake fault. Seeing only the shallower portion of the SI fault than the Iburi fault $(Z<8.8 \mathrm{~km}), \triangle \mathrm{CFF}(0)$ is always positive and has a value of $0.23 \mathrm{MPa}$ at point I1 in Fig. 5c. The northern and southern faults have identical dip angle and comparable strike, which results in similar $\triangle \mathrm{CFF}(0)$ distributions (Fig. $5 \mathrm{a}, \mathrm{b}$ ). The cross sections indicate that negative- $\triangle \mathrm{CFF}(0)$ regions in these two cases are narrower than those in the case for the SI fault. However, the northern and southern faults traverse the narrowed negative- $\triangle \mathrm{CFF}(0)$ regions, such that $\triangle \mathrm{CFF}(0)$ is negative at mid-depths and positive at deeper and shallower portions along the faults (Fig. $5 \mathrm{a}, \mathrm{b}$ ). The $\triangle \mathrm{CFF}(0)$ value ranges from -0.14 to $0.22 \mathrm{MPa}$ along the southern half of the northern fault, whereas the $\triangle \mathrm{CFF}(0)$ value in the northern half is negligible. Along the southern fault, the $\triangle \mathrm{CFF}(0)$ ranges from -0.17 to $0.34 \mathrm{MPa}$. The magnitude of the $\triangle \operatorname{CFF}(0)$ is larger along the southern fault compared with the northern fault because the former is closer to the Iburi earthquake fault than the latter. We observe that, in all of the target faults, regions exist along the fault plane where $\triangle \mathrm{CFF}(0)$ exceeds the earthquake triggering threshold of $0.01 \mathrm{MPa}$ (Stein 1999).

The development of viscoelastic deformation modifies the $\triangle C F F$ as time goes. Hereafter we refer to the postseismic change in $\triangle \mathrm{CFF}$ after the mainshock, $\Delta \operatorname{CFF}(t)-\Delta \operatorname{CFF}(0)$, as post- $\Delta \mathrm{CFF}$. Figure 6 shows the post- $\Delta C F F$ for $t=10$ years; $\Delta \operatorname{CFF}(10$ year $)-\Delta \operatorname{CFF}(0)$. Similar to the coseismic $\triangle$ CFF distribution, the distribution of the post- $\triangle C F F$ along the northern and southern faults show a similar pattern to each other. However, as shown by a comparison of the cross sections (Figs. 5, 6), the sign of the post- $\Delta C F F$ tends to be the opposite of the sign of $\triangle \mathrm{CFF}(0)$ because the postseismic deformation relaxes the imposed coseismic strain in the viscoelastic region (Freed and Lin 1998; Freed 2005). Here, the postseismic stressing source seems to be the inelastic strain in the viscoelastic region (the region deeper than the dotted line in Fig. 6) around the deeper end of the Iburi earthquake fault, i.e., approximately $0 \mathrm{~km}<X<40 \mathrm{~km}$ and $-10 \mathrm{~km}<Y<30 \mathrm{~km}$, where exhibits large post- $\Delta C F F$ value. This inelastic strain generates the positive post$\triangle C F F$ in the shallow western part of the Iburi fault and negative post- $\triangle C F F$ in the shallow eastern part, in the cross-sectional view (Fig. 6a, b bottom). The northern and southern faults are adjacent to the boundary of the positive/negative post- $\Delta C F F$ values. Then, the value of the post- $\triangle C F F$ along the northern and southern faults is positive at shallower portions and negative at deeper portions, respectively (Fig. 6a, b top). For the SI fault, the entire fault is located in the positive lobe of the post$\triangle$ CFF (Fig. 6c).

In Fig. $7 \mathrm{a}$ (solid lines), we show the $\Delta \operatorname{CFF}(t)$ at three points, S1, S2, and S3, on the southern fault, as indicated in Fig. 6b (black circles). These points are representative of the shallow, middle, and deep portions of the southern fault, respectively. At S3 (deep), the Iburi earthquake gives a positive $\triangle \mathrm{CFF}(0)$ of $0.3109 \mathrm{MPa}$, which decreases by $0.0216 \mathrm{MPa}(0.0339 \mathrm{MPa})$ during the 10 years (20 years) following the mainshock. At S1 (shallow), the $\triangle \mathrm{CFF}(0)$ is $0.0901 \mathrm{MPa}$ and further increases by $0.0122 \mathrm{MPa}(0.0194 \mathrm{MPa})$ during the 10 years (20 years) following the mainshock. At both points, the post- $\Delta \mathrm{CFF}$ for the 2 decades after the mainshock is one order of magnitude smaller than the coseismic $\triangle C F F$. On the other hand, at $\mathrm{S} 2$ (middle), the $\triangle \mathrm{CFF}(0)$ is $-0.1238 \mathrm{MPa}$, and $\triangle C F F$ does not change substantially after that (increase by only $0.0006 \mathrm{MPa}$ during the 10 years following the mainshock). This negligible post- $\Delta$ CFF value is because S2 is located near node points, at which the post- $\Delta C F F$ value changes its sign (Fig. $6 \mathrm{~b}$ bottom). Although we do not show the figure here, a similar Coulomb stress evolution was observed along the southern half of the northern fault. For the SI fault, the value of post- $\triangle C F F$ along the entire fault is always positive after the mainshock. The $\triangle \mathrm{CFF}$ value at point I1 (Fig. 6c black circle) increases by $0.0165 \mathrm{MPa}(0.0257 \mathrm{MPa})$ during the 10 years (20 years) after the coseismic $\triangle$ CFF value of $0.2270 \mathrm{MPa}$ (Fig. $7 \mathrm{~b}$ solid line). Similar to the points on the southern fault, the amount of post- $\triangle \mathrm{CFF}$ for 2 decades after the mainshock is one order of magnitude smaller than that of coseismic $\triangle$ CFF.

In addition to the case of $\mu^{\prime}=0.4$ shown above, we also have examined the cases of $\mu^{\prime}=0.1$ and 0.7. The resultant distributions of coseismic and postseismic $\triangle \mathrm{CFF}$ showed similar patterns to those in the case of $\mu^{\prime}=0.4$, and the magnitude of $\Delta$ CFF increased with increasing $\mu^{\prime}$. 


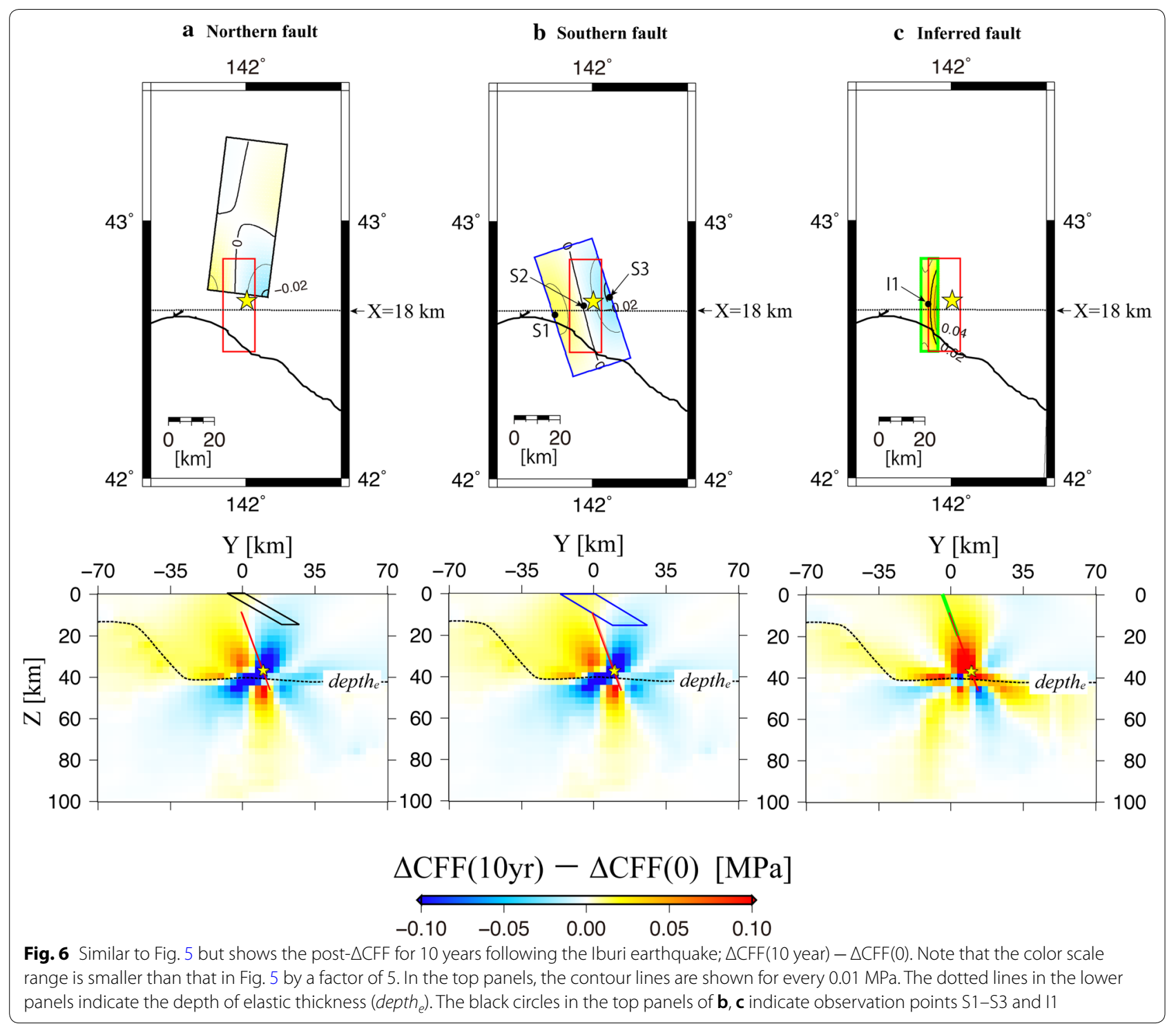

\section{Discussion}

\section{Variation in viscoelastic structure}

Prior to discussing the seismic potential of the target faults, we investigate the effect that viscoelastic structure uncertainty has on the computed Coulomb stress. In the previous section, we showed results for $\eta=1 \times 10^{19} \mathrm{~Pa} \mathrm{~s}$, though the representative viscosity of the lower crust is not well constrained. Iio et al. (2004) argued that viscosity in the lower crust is high, except for fault zones. Here, we computed the Coulomb stress for a scenarios with high viscosity, $\eta=1 \times 10^{20} \mathrm{~Pa}$ s, to examine how viscosity influences our results. Dashed lines in Fig. 7a show the evolution of $\triangle \mathrm{CFF}$ at the points $\mathrm{S} 1-\mathrm{S} 3$ on the southern fault. During the 10 years following the mainshock, the $\triangle \mathrm{CFF}$ changes $0.0015 \mathrm{MPa}$ at $\mathrm{S} 1,-0.0027 \mathrm{MPa}$ at
$\mathrm{S} 2$, and $-0.0003 \mathrm{MPa}$ at $\mathrm{S}$, which amount is one order of magnitude smaller than the case of $\eta=1 \times 10^{19} \mathrm{~Pa} \mathrm{~s}$. Then, in the case of $\eta=1 \times 10^{20} \mathrm{~Pa} \mathrm{~s}$, the amount of post- $\triangle \mathrm{CFF}$ for the 2 decades following the mainshock is two orders of magnitude smaller than that of coseismic $\triangle \mathrm{CFF}$, which suggests that the postseismic effects of triggering a rupture along the target faults, in the case of $\eta=1 \times 10^{20} \mathrm{~Pa} \mathrm{~s}$, will be small. This is the same for the SI fault (Fig. 7b). We note that the sense of the evolution of the $\triangle$ CFF does not change regardless of the viscosity value.

We also computed $\triangle \mathrm{CFF}(t)$ by assuming a 1 -D viscoelastic structure to examine the effects of the 3-D structure. We specifically aimed to understand how a laterally homogeneous simple-layered model causes 
a Southern fault



b Inferred fault

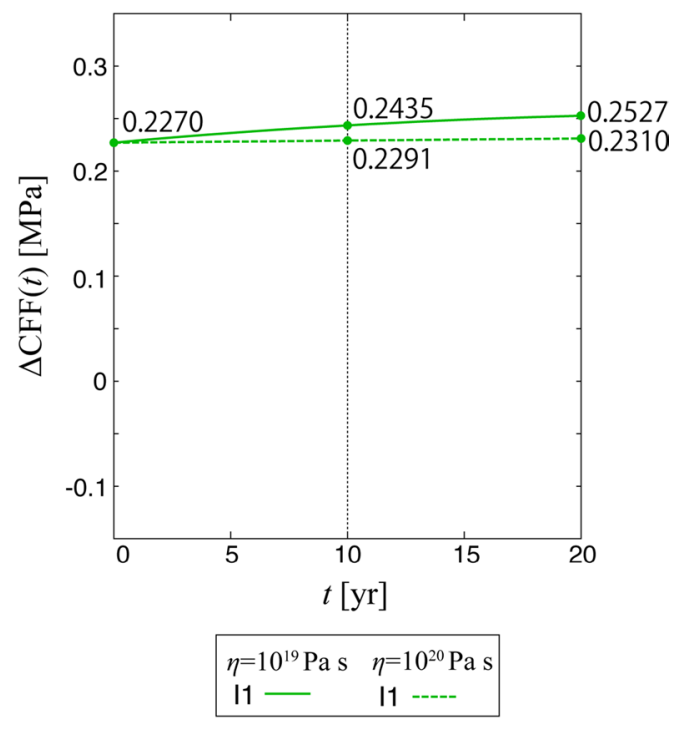

Fig. 7 Time evolution of $\triangle \mathrm{CFF}(t)$ at three points along the southern fault (S1-S3 in Fig. 6b) and the point along the SI fault (I1 in Fig. 6c). The solid and dashed lines indicate the cases for $\eta=10^{19} \mathrm{~Pa}$ s and $10^{20} \mathrm{~Pa}$ s, respectively

a bias in the estimation of the time-dependent Coulomb stress. For the 1-D structure, we set $\operatorname{depth}_{e}(\mathbf{x})$ to $40.49 \mathrm{~km}$, i.e., uniform throughout the entire area. We selected a value that is identical to the 3 -D structure just below the hypocenter of the mainshock. Here, we ignore the plate subduction. For a scenario using the 1 -D structure (1-D case), we set the viscoelastic region to $40.49 \mathrm{~km}<Z<170.0 \mathrm{~km}$. Figure 8 a shows the post$\triangle \mathrm{CFF}$ for 10 years after the Iburi earthquake in the 1 -D case. We observe quite similar post- $\triangle$ CFF to that in the 3-D case (Fig. 6b). Although we only show the southern fault, this trend is the same for the other target faults. The postseismic stressing source, which seems to locate approximately $0 \mathrm{~km}<X<40 \mathrm{~km}$ and $-10 \mathrm{~km}<Y<30 \mathrm{~km}$, is also identical for the 3-D case. Similar post- $\triangle C F F$ distributions between the two cases are due to a comparable elastic thickness depth of $\sim 40 \mathrm{~km}$ around the postseismic stressing source (Figs. 4b, 6).

Figure $8 \mathrm{~b}$ shows the postseismic deformation on the ground surface in the E-W direction during the 10 years following the mainshock for the 3-D (Fig. 8b top) and 1-D cases (bottom left). A large amount of deformation is observed above the Iburi earthquake fault and in the east side. The magnitude in the former case is approximately 0.6 times smaller than that in the latter case. However, the location of the area of large deformation does not differ substantially, and the stressing source area around $0 \mathrm{~km}<X<40 \mathrm{~km}$ and $-10 \mathrm{~km}<Y<30 \mathrm{~km}$, same with that in the 3-D case, is also inferred. Then the bias due to assuming the 1-D structure appears small. This result does not assert that the 1-D structure assumption is always reasonable. It just happened that the influence on the target faults in the present study was small.

Lastly, we show the results calculated using the method of Fukahata and Matsu'ura $(2005,2006)$, by assuming the same 1-D structure shown above to validate the results from our numerical code. We should note that the viscoelastic region in our method is set only in the limited region where viscoelastic cuboid cells were assigned. On the other hand, the case using Fukahata and Matsu'ura assumes a viscoelastic layer, which spreads infinitely in $X, Y$, and $Z>$ depth $_{e}=40.49 \mathrm{~km}$. Therefore, strictly speaking, the viscoelastic structure differs in locations that are far from the mainshock fault. The surface deformation for the case using the method of Fukahata and Matsu'ura (Fig. 8b bottom right) is similar to that in our 1-D case (Fig. $8 \mathrm{~b}$ bottom left), which demonstrates the validity of our numerical code. This result also indicates that the viscoelastic volumetric cells, set in our model, are sufficient to calculate the post- $\Delta C F F$ at least along the target faults.

\section{Evaluation of seismic potentials}

Our results indicate that the $\triangle \mathrm{CFF}$ distribution varies even along each target fault. Along the southern fault, we observed the positive value of the coseismic $\triangle C F F$ in the deeper portion, suggesting that the portion is brought closer to the rupture due to the Iburi earthquake. The 
a Southern fault (1-D case)
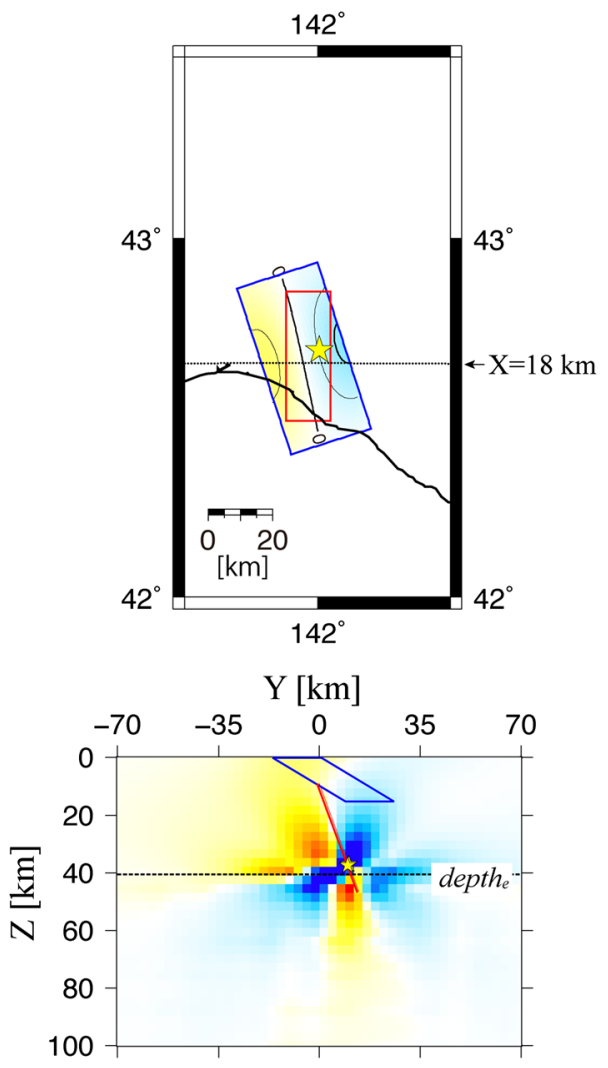

$\Delta \mathrm{CFF}(10 \mathrm{yr})-\triangle \mathrm{CFF}(0)[\mathrm{MPa}]$

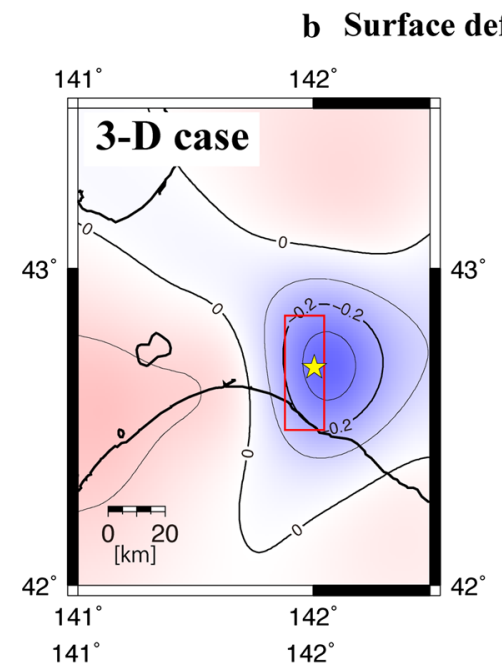

$43^{\circ}$

Surface deformation in $\mathrm{E}-\mathrm{W}$ direction $[\mathrm{cm}]$

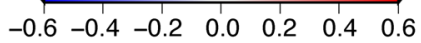

$\begin{array}{llllllll}-0.6 & -0.4 & -0.2 & 0.0 & 0.2 & 0.4 & 0.6\end{array}$
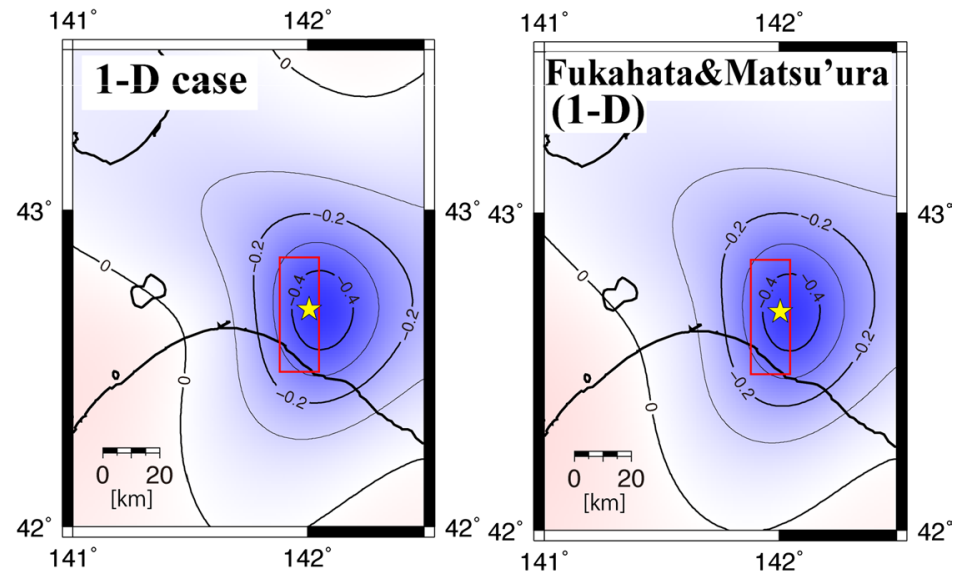

$\begin{array}{lllll}-0.10 & -0.05 & 0.00 & 0.05 & 0.10\end{array}$

Fig. 8 a Post- $\triangle C F F$ distribution for the southern fault calculated assuming the 1-D viscoelastic structure. See the captions of Figs. 5 and 6 for an explanation of the figure. $\mathbf{b}$ Surface deformation in the E-W direction (eastward positive) for 10 years following the lburi earthquake. The top and bottom left panels show the calculated deformation patterns for the 3-D and 1-D viscoelastic structures, respectively. The right bottom panel also shows the computed E-W deformation assuming the 1-D viscoelastic structure but calculated using methods of Fukahata and Matsu'ura (2005, 2006)

increases in the $\triangle \mathrm{CFF}$ do not always indicate the immediate seismic triggering, even when enough stress for a rupture is imposed on the fault. This is because of a "delayed failure" nature of the rate- and state-dependent friction (Dieterich 1979), which is a more realistic friction than classic Coulomb friction. Though a large earthquake has not happened on the southern fault yet, after the mainshock, the positive value of the coseismic $\triangle \mathrm{CFF}$ indicates a higher seismic risk for a certain period after the mainshock. Our calculation indicates that postseismic viscoelastic relaxation lowers the $\triangle \mathrm{CFF}$ from the coseismic value. However, the risk of the delayed trigger of an earthquake remains for a certain period, because the magnitude of the stress decrease is insufficient to return the stress level to that before the Iburi earthquake, at least for a few decades after the Iburi earthquake. The middle portion of the fault was brought away from rupture just after the Iburi earthquake, because the value of the coseismic $\triangle \mathrm{CFF}$ is negative, and this situation does not change for a few decades due to negligible changes in postseismic stress. The shallower portion of the southern fault has a positive coseismic $\triangle C F F$ value, which further increases after the mainshock because of viscoelastic relaxation. Therefore, the shallow portion was brought closer to rupture just after the mainshock, and seismic risk continuously increases for decades after the mainshock. These depth-dependent features are also true for the southern half of the northern fault. The coexistence of positive and negative $\triangle \mathrm{CFF}$ values along a fault plane may influence the size of future earthquakes, depending 
on the role that negative stress regions play during dynamic rupture propagation.

As previously mentioned in Introduction, the most recent event along the northern fault presumably occurred within a few hundred years or less. By taking into account the 1000-2000 year recurrence interval, Headquarters for Earthquake Research Promotion (2010) evaluated the probability of an earthquake within the next 30 years is nearly $0 \%$. However, the paleoseismic data suggest that the most recent event is restricted to the central part of the northern fault and has not been found on the southern part where the $\triangle \mathrm{CFF}$ values exceeded the earthquake triggering threshold. If the southern part of the fault remains unbroken, our results suggest that high seismic potential is left there, especially for moderate-sized earthquakes. As for the southern fault, we have no knowledge of an accurate recurrence interval and the elapsed time since the last event, which makes it difficult to evaluate the seismic potential of this fault. Nevertheless, this fault is one of the precaution faults considering that it has a high slip tendency under the present-day stress field (Fig. 3), and furthermore, it received large positive stress change as mentioned above. We conclude that the southern fault, as well as a part of the northern fault, is in a state that seismic risk has increased after the mainshock.

In this study, we also focused on a previously unknown fault (SI fault), which was subject to the largest stress increase among the target faults. The most of the fault plane is brought close to failure by the coseismic stress change due to the mainshock, as well as by the postseismic stress change at least for a few decades after the mainshock. The location and geometry of the SI fault derive from aftershock distributions, where background seismicity was low. We note that the calculated $\triangle \mathrm{CFF}$ is consistent with the activation of seismicity there. The $\triangle C F F$ value continues to increase over many years after the mainshock, which may imply a growing risk of seismic hazards along the SI fault. The empirical relationship between the rupture area and moment magnitude (Wells and Coppersmith 1994) indicates that the SI fault has the potential to produce an $M_{\mathrm{w}} \sim 7$ earthquake. To evaluate the risk of the earthquake hazards in this region, it is necessary to take this previously unknown fault into consideration.

Lastly, we comment about the seismic triggering threshold for postseismic stress change. The amount of the post- $\triangle C F F$ for 10 years after the mainshock is $0.0122 \mathrm{MPa}$ at point S1 and $0.0165 \mathrm{MPa}$ at point I1, both of which are greater than the seismic trigger threshold shown in Stein (1999), 0.01 MPa. We should note that this threshold is derived for the coseismic stress change. When we consider the rate- and state-dependent friction, if it takes time to increase the stress, the triggering effect will be smaller than that for an instantaneous increase. This is because friction strength can increase during this period via healing mechanisms. Although future studies are required to evaluate the triggering threshold for the postseismic stress change, we believe that the consideration of time-dependent stress change is crucial for evaluating seismic potential and reliable assessments of seismic hazard.

\section{Summary}

We examined the seismic potential for the region around the 2018 Hokkaido Eastern Iburi earthquake (Iburi earthquake) fault, based on seismological analysis and numerical simulations. In the vicinity of the Iburi earthquake, there is an active fault zone known as the eastern boundary fault zone of the Ishikari lowland, which consists of the northern and southern faults. The shallow aftershock distribution also suggests the existence of a previously unknown fault (SI fault) at a shallower extension of the Iburi earthquake fault. In the present study, we focused on the evaluation of seismic potential of the SI fault, together with the northern and southern faults.

The seismicity around the target faults was low before the Iburi earthquake. The focal mechanism solutions for the shallow aftershocks of the Iburi earthquake, which are located at a depth around the target faults, provide an opportunity to infer the present-day stress field. We estimated the stress field as ENE-SWS compressional, which is considered to be a consequence of westward migration of the Kuril Arc sliver and its collision with northeastern Japan. Slip tendency analysis indicates that all the target faults originally have high slip potential under the estimated present-day stress field.

We then evaluated the potential for earthquake occurrence along the target faults affected by the Iburi earthquake. We calculated the time-dependent Coulomb stress $(\triangle \mathrm{CFF})$ due to the Iburi earthquake, taking into account postseismic viscoelastic relaxation with a $3-D$ viscoelastic structure. Note that the result shown in the present paper provides one possible scenario derived from a model that uses information currently available. After the mainshock, the viscoelastic deformation occurs in the viscoelastic layer around the deeper end of the Iburi earthquake fault to relax the imposed coseismic stress. The elastic thickness is almost uniform around there, so the biases in the estimation of $\triangle \mathrm{CFF}$ when assuming a 1-D viscoelastic structure were small.

The $\triangle$ CFF distribution along the southern fault and southern half of the northern fault had a similar depthdependent pattern. The faults were brought closer to rupture just after the Iburi earthquake, which is indicated by the positive $\triangle \mathrm{CFF}$ values, except for middle depths 
along the faults. The $\triangle \mathrm{CFF}$ value increases in the shallow portion after the Iburi earthquake due to the postseismic process, suggesting a continuous stress build-up for many years following the mainshock. Although the $\triangle \mathrm{CFF}$ value decreases in the deep portion as time goes on after the mainshock, it is insufficient to return the pre-shock stress level, at least for a few decades. These results suggest that the northern and southern faults are in a state of increasing seismic risk after the mainshock.

The most of the SI fault was brought closer to rupture just after the mainshock, indicated by the positive $\triangle \mathrm{CFF}$ values. This is consistent with the activation of seismicity in this region. The $\triangle \mathrm{CFF}$ value continues to increase over many years following the mainshock, which may imply a growing seismic risk. It is, therefore, necessary to consider this previously unknown fault when evaluating future seismic risks in this region.

All target faults experiences the postseismic positive $\triangle$ CFF changes for 2 decades following the Iburi earthquake, which is greater than the seismic triggering threshold $(0.01 \mathrm{MPa})$. This result suggests that time-dependent changes in stress are crucial to evaluate seismic potential and have reliable assessments of seismic hazards, despite the need for more studies on the magnitude of triggering threshold.

\section{Acknowledgements \\ We thank two anonymous reviewers for their comments and suggestions that helped to improve the manuscript. We used Japan Meteorological Agency (JMA) earthquake catalog. Seismic stations used in this study include perma- nent stations operated by Hokkaido University, the National Research Institute for Earth Science and Disaster Resilience (Hi-net), and JMA. We used "Slick Package" (http://earthquake.usgs.gov/research/software/) software coded by Andrew Michael for the stress tensor inversion. The figures were drawn using GMT (Wessel and Smith 1998).}

\section{Authors' contributions}

All authors designed the present study. Kl performed stress analysis using seismic data and wrote "Slip tendency of the target faults under the presentday stress field" section of the manuscript. MO calculated the Coulomb stress and drafted the remaining parts of the manuscript. All authors discussed the results and contributed to the final manuscript. Both authors read and approved the final manuscript.

\section{Funding}

This work was supported by JSPS KAKENHI Grant Number JP16K17789.

\section{Availability of data and materials}

The seismic datasets used in this article are available on Hi-net (http://www. doi.org/10.17598/NIED.0003) from NIED.

\section{Competing interests}

The authors declare that they have no competing interests.

Received: 29 January 2019 Accepted: 13 May 2019

Published online: 22 May 2019

\section{References}

Barbot S, Fialko Y (2010) A unified continuum representation of postseismic relaxation mechanisms: semi-analytic models of afterslip, poroelastic rebound and viscoelastic flow. Geophys J Int 182(3):1124-1140. https:// doi.org/10.1111/j.1365-246X.2010.04678.x

Barbot S, Moore JD, Lambert V (2017) Displacement and stress associated with distributed anelastic deformation in a half-space. Bull Seismol Soc Am 107(2):821-855. https://doi.org/10.1785/0120160237

Cho I, Kuwahara Y (2013a) Constraints on the three-dimensional thermal structure of the lower crust in the Japanese Islands. Earth Planets Space 65:855-861. https://doi.org/10.5047/eps.2013.01.005

Cho I, Kuwahara Y (2013b) Numerical simulation of crustal deformation using a three-dimensional viscoelastic crustal structure model for the Japanese islands under east-west compression. Earth Planet Space 65:1041-1046. https://doi.org/10.5047/eps.2013.05.006

Collettini C, Trippetta F (2007) A slip tendency analysis to test mechanical and structural control on aftershock rupture planes. Earth Planet Sci Lett 255:402-413. https://doi.org/10.1016/j.epsl.2007.01.001

Dieterich JH (1979) Modeling of rock friction: 1. Experimental results and constitutive equations. J Geophys Res Solid Earth 84(5):2161-2168. https ://doi.org/10.1029/JB084iB05p02161

Flohlich C (1992) Triangle diagrams: ternary graphs to display similarity and diversity of earthquake focal mechanism. Phys Earth Planet Inter 75:193-198. https://doi.org/10.1016/0031-9201(92)90130-N

Freed AM (2005) Earthquake triggering by static, dynamic, and postseismic stress transfer. Annu Rev Earth Planet Sci 33:335-367. https://doi. org/10.1146/annurev.earth.33.092203.122505

Freed AM, Lin J (1998) Time-dependent changes in failure stress following thrust earthquakes. J Geophys Res Solid Earth 103(B10):24393-24409. https://doi.org/10.1029/98JB01764

Fukahata Y, Matsu'ura M (2005) General expressions for internal deformation fields due to a dislocation source in a multilayered elastic half-space. Geophys J Int 161:507-521. https://doi.org/10.1111/j.1365-246X.2005.02594.x

Fukahata Y, Matsu'ura M (2006) Quasi-static internal deformation due to a dislocation source in a multilayered elastic/viscoelastic half-space and an equivalence theorem. Geophys J Int 166:418-434. https://doi. org/10.1111/j.1365-246X.2006.02921.X

Geospatial Information Authority of Japan (2018) The 2018 Hokkaido Eastern Iburi earthquake: fault model (preliminary). http://www.gsi.go.jp/cais/ topic180912-index-e.html. Accessed 29 Jan 2019

Hairer E, Nørsett SP, Wanner G (1993) Solving ordinary differential equations I-nonstiff problems. Springer series in computational mathematics, vol 8, 2nd edn. Springer, Heidelberg

Headquarters for Earthquake Research Promotion (2010) Long-term evaluation of the eastern boundary fault zone of Ishikari lowland. https://www. jishin.go.jp/main/chousa/10aug_ishikari/index.htm. Accessed 29 Jan 2019 (in Japanese)

Hirata N, Matsu'ura M (1987) Maximum-likelihood estimation of hypocenter with origin time eliminated using nonlinear inversion technique. Phys Earth Planet Inter 47:50-61. https://doi.org/10.1016/0031-9201(87)90066 $-5$

lio Y, Sagiya T, Kobayashi Y (2004) Origin of the concentrated deformation zone in the Japanese Islands and stress accumulation process of intraplate earthquakes. Earth Planets Space 56:831-842. https://doi.org/10.1186/ BF03353090

Imanishi K, Kuwahara Y, Takeda T, Mizuno T, Ito H, Ito K, Wada H, Haryu Y (2011) Depth-dependent stress field in and around the Atotsugawa fault, central Japan, deduced from microearthquake focal mechanisms: evidence for localized aseismic deformation in the downward extension of the fault. J Geophys Res 116:B01305. https://doi.org/10.1029/2010JB007900

Itoh Y, Nishimura T (2016) Characteristics of postseismic deformation following the 2003 Tokachi-oki earthquake and estimation of the viscoelastic structure in Hokkaido, northern Japan. Earth Planets Space 68:156. https ://doi.org/10.1016/s40623-016-0533-y

Iwasaki T, Adachi K, Moriya T, Miyamachi H, Matsushima T, Miyashita K, Takeda T, Taira T, Yamada T, Ohtake K (2004) Upper and middle crustal deformation of an arc-arc collision across Hokkaido, Japan, inferred from seismic refraction/wide-angle reflection experiments. Tectonophysics 388:59-73. https://doi.org/10.1016/j.tecto.2004.03.025

Japan Meteorological Agency (2018) A preliminary result of source process of the 2018 Hokkaido Eastern Iburi earthquake derived from near-source strong motion data. https://www.data.jma.go.jp/svd/egev/data/sourc eprocess/event/2018090603075933near.pdf. Accessed 29 Jan 2019 (in Japanese) 
Japan Meteorological Agency (2019) Evaluation of the Hokkaido Middle Eastern Iburi earthquake on February 21, 2019. https://www.static.jishi n.go.jp/resource/monthly/2019/20190221_iburi_1.pdf. Accessed 09 April 2019 (in Japanese)

Kimura G (1986) Oblique subduction and collision: forearc tectonics of the Kuril arc. Geology 14:404-407. https://doi.org/10.1130/00917613(1986)14\%3c404:OSACFT\%3e2.0.CO;2

King GCP, Cocco M (2001) Fault interaction by elastic stress changes: new clues from earthquake sequences. Adv Geophys 44:1-38. https://doi. org/10.1016/S0065-2687(00)80006-0

King GCP, Stein RS, Lin J (1994) Static stress changes and the triggering of earthquakes. Bull Seismol Soc Am 84(3):935-953

Kita S, Okada T, Hasegawa A, Nakajima J, Matsuzawa T (2010) Anomalous deepening of a seismic belt in the upper-plane of the double seismic zone in the Pacific slab beneath the Hokkaido corner: possible evidence for thermal shielding caused by subducted forearc crust materials. Earth Planet Sci Lett 290(3-4):415-426. https://doi.org/10.1016/j. epsl.2009.12.038

Kita S, Hasegawa A, Nakajima J, Okada T, Matsuzawa T, Katsumata K (2012) High-resolution seismic velocity structure beneath the Hokkaido corner, northern Japan: arc-arc collision and origins of the 1970 M 6.7 Hidaka and 1982 M 7.1 Urakawa-oki earthquakes. J Geophys Res 117:12301. https://doi.org/10.1029/2012JB009356

Lambert V, Barbot S (2016) Contribution of viscoelastic flow in earthquake cycles within the lithosphere-asthenosphere system. Geophys Res Lett 43(19):10-142. https://doi.org/10.1002/2016GL070345

Lin J, Stein RS (2004) Stress triggering in thrust and subduction earthquakes and stress interaction between the southern San Andreas and nearby thrust and strike-slip faults. J Geophys Res 109:B02303. https://doi. org/10.1029/2003JB002607

Lisle RJ, Srivastava DC (2004) Test of the frictional reactivation theory for faults and validity of fault-slip analysis. Geology 32(7):569-572. https://doi. org/10.1130/G20408.1

Matsubara M, Sato H, Ishiyama T, Van Horne A (2017) Configuration of the Moho discontinuity beneath the Japanese Islands derived from threedimensional seismic tomography. Tectonophysics 710-711:97-107. https ://doi.org/10.1016/j.tecto.2016.11.025

Michael AJ (1984) Determination of stress from slip data: faults and folds. J Geophys Res 89(B13):11517-11526. https://doi.org/10.1029/JB089iB13p 11517

Michael AJ (1987) Use of focal mechanisms to determine stress: a control study. J Geophys Res 92:357-368. https://doi.org/10.1029/JB092iB01p 00357

Morris A, Ferrill DA, Henderson DB (1996) Slip-tendency analysis and fault reactivation. Geology 24:275-278. https://doi.org/10.1130/00917613(1996)24\%3c0275:STAAFR\%3e2.3.CO;2
Nakajima J, Hasegawa A (2006) Anomalous low-velocity zone and linear alignment of seismicity along it in the subducted Pacific slab beneath Kanto, Japan: reactivation of subducted fracture zone? Geophys Res Lett 33:L16309. https://doi.org/10.1029/2006GL026773

Ohzono M, Ohta Y, linuma T, Miura S, Muto J (2012) Geodetic evidence of viscoelastic relaxation after the 2008 Iwate-Miyagi Nairiku earthquake. Earth Planets Space 64:759-764. https://doi.org/10.5047/eps.2012.04.001

Okada Y (1992) Internal deformation due to shear and tensile faults in a halfspace. Bull Seismol Soc Am 82(2):1018-1040

Omuralieva AM, Hasegawa A, Matsuzawa T, Nakajima J, Okada T (2012) Lateral variation of the cutoff depth of shallow earthquakes beneath the Japan Islands and its implications for seismogenesis. Tectonophysics 518:93-105. https://doi.org/10.1016/j.tecto.2011.11.013

Reasenberg PA, Simpson RW (1992) Response of regional seismicity to the static stress change produced by the Loma Prieta earthquake. Science 255(5052):1687-1690. https://doi.org/10.1126/science.255.5052.1687

Research Group for Active Faults of Japan (1991) Active Faults of Japan. University of Tokyo Press, Tokyo (in Japanese)

Stein RS (1999) The role of stress transfer in earthquake occurrence. Nature 402(6762):605-609. https://doi.org/10.1038/45144

Suito H, Hirahara K (1999) Simulation of postseismic deformations caused by the 1896 Riku-u Earthquake, northeast Japan: re-evaluation of the viscosity in the upper mantle. Geophys Res Lett 26:2561-2564. https://doi. org/10.1029/1999GL900551

Ueda H, Ohtake M, Sato H (2003) Postseismic crustal deformation following the 1993 Hokkaido Nansei-oki earthquake, northern Japan: evidence for a low-viscosity zone in the uppermost mantle. J Geophys Res 108(B3):2151. https://doi.org/10.1029/2002JB002067

Wells DL, Coppersmith KJ (1994) New empirical relationships among magnitude, rupture length, rupture width, rupture area, and surface displacement. Bull Seismol Soc Am 84(4):974-1002

Wessel P, Smith WHF (1998) New, improved version of the generic mapping tools released. EOS Trans Am Geophys Union 79:579. https://doi. org/10.1029/98EO00426

Yukutake Y, Takeda T, Yoshida A (2015) The applicability of frictional reactivation theory to active faults in Japan based on slip tendency analysis. Earth Planet Sci Lett 411:188-198. https://doi.org/10.1016/j.epsl.2014.12.005

\section{Publisher's Note}

Springer Nature remains neutral with regard to jurisdictional claims in published maps and institutional affiliations.

\section{Submit your manuscript to a SpringerOpen ${ }^{\circ}$ journal and benefit from:}

- Convenient online submission

- Rigorous peer review

- Open access: articles freely available online

- High visibility within the field

- Retaining the copyright to your article

Submit your next manuscript at $\boldsymbol{\nabla}$ springeropen.com 